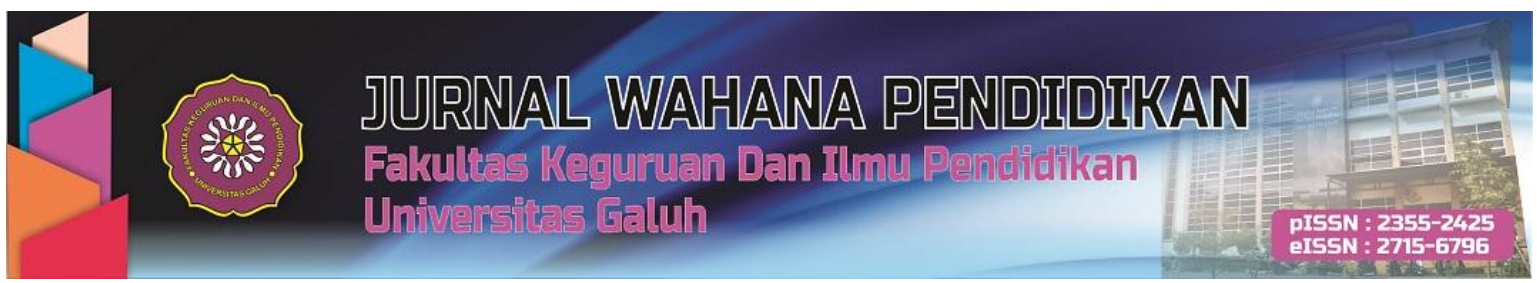

https://jurnal.unigal.ac.id/index.php/jwp

\title{
HUBUNGAN PERSENTASE LEMAK TUBUH TERHADAP TINGKAT KEBUGARAN JASMANI
}

\author{
Andang Rohendi ${ }^{1}$, Hendra Rustiawan ${ }^{1}$, Sri Maryati ${ }^{1}$ \\ 1Program Studi Pendidikan Jasmani \\ Universitas Galuh, Jl. R. E. Martadinata No.150, Ciamis, Indonesia \\ Email: hendra6610111972@gmail.com
}

\begin{abstract}
The purpose of this research was to find out the relationship between body fat percentage and physical fitness level. This study used a correlational method which was carried out in a cross to link one variable to another without taking so much time. The population in this study was students on the basketball class at the State Senior High School in Ciamis, Indonesia. The samples were 30 students. The data were taken from high school level physical fitness tests and measurement of body fat percentage with skinfold/fat calliper. The data collecting and processing used SPSS 22 series was. The results showed that there was no relationship between body fat percentage and physical fitness level. Based on probability values, if probability $>0.05, \mathrm{H} 0$ is accepted, and if chance $<0.05, \mathrm{H} 0$ is rejected. Based on the results of calculations for physical fitness variables with a percentage of body fat (\% Fat) the significance number obtained was 0.601 , the figure is above 0.05 then $\mathrm{H} 0$ is accepted. Thus, although there is a relationship between physical fitness with a percentage of body fat, the link is not significant.
\end{abstract}

Keywords: Body fat percentage, Physical fitness, and Sports class.

\section{ABSTRAK}

Tujuan penelitian ini adalah untuk mengetahui seberapa besar hubungan persentase lemak tubuh dengan tingkat kebugaran jasmani. Penelitian ini menggunakan metode korelasional yang dilakukan secara cross sectional dengan tujuan untuk menghubungkan satu variabel dengan variabel lain tanpa memperhitungkan waktu. Populasi pada penelitian ini adalah siswa kelas olahraga pada cabang olahraga Bola basket SMA N 3 Kabupaten Ciamis. Jumlah sampel penelitian sebanyak 30 orang. Pengambilan data menggunakan tes kebugaran jasmani tingkat SMA dan pengukuran persentase lemak tubuh dengan skinfold/fat califer. Pengolahan dan analisis data menggunakan aplikasi statistika SPSS serie 22. Hasil penelitian memperlihatkan bahwa tidak adanya hubungan antara persentase lemak tubuh dengan tingkat kebugaran jasmani. Adapun ketentuannya berdasarkan nilai probabilitas yaitu : jika probabilitas > $0.05, \mathrm{HO}$ diterima, dan jika probabilitas $<0.05, \mathrm{HO}$ ditolak. Berdasarkan pada hasil perhitungan untuk variabel kesegaran jasmani dengan persentase lemak tubuh (\% Fat) angka signifikansi diperoleh sebesar 0.601, angka tersebut di atas 0.05 maka HO diterima. Dengan demikian walaupun ada hubungan antara kesegaran jasmani dengan persentase lemak tubuh, tetapi hubungannya tidak signifikan.

Kata Kunci: Persentase lemak tubuh, Kebugaran jasmani, Kelas olahraga

Cara sitasi:

Rohendi, A., Rustiawan, H., \& Maryati, S. (2020). Hubungan persentase lemak tubuh terhadap tingkat kebugaran jasmani. Jurnal Wahana Pendidikan, 7 (1), 01-08. 


\section{PENDAHULUAN}

Kebugaran jasmani adalah suatu keadaan yang dimiliki atau dicapai seseorang dalam kaitannya dengan kemampuan untuk melakukan aktivitas fisik yang dimaksud adalah olahraga. Kebugaran jasmani berkaitan dengan kesehatan ketika aktivitas fisik dapat dilakukan tanpa kelelahan berlebihan, terpelihara seumur hidup dan sebagai konsekuensinya memiliki risiko lebih rendah untuk terjadinya penyakit kronik lebih awal (Sulasmono \& Fatkur Rohman K, 2016). Seseorang yang secara fisik bugar dapat melakukan aktivitas fisik sehari-harinya dengan giat, memiliki risiko rendah dalam masalah kesehatan dan dapat menikmati olahraga serta berbagai aktivitas (Annas Buanasita, Andriyanto, 2015).

Di bawah ini ada beberapa pengertian kebugaran jasmani dari beberapa ahli pendiddikan jasmani dan olahraga prestasi. Kebugaran Jasmani adalah kemampuan untuk menyelesaikan tugas sehari-hari dengan tenaga dan kesiap siagaan, tanpa kelelahan yang berarti dan dengan energi yang relatif cukup untuk pencapaian pemenuhan waktu luang dan keadaan darurat yang tak terduga (Larsen, 2011). Pengertian lain tentang kebugaran jasmani adalah kemampuan fungsi kerja tubuh secara efektif seperti olaraga atau aktivitas lain yang masih memiliki energi untuk mengontrol diri atau kebutuhan energy secara tiba-tiba.

Kesadaran akan pentingnya olahraga dalam meningkatkan kebugaran jasmani pada masyarakat harus ditingkatkan. Beberapa cara untuk mengingatkan akan pentingnya olahraga seperti banyak lapangan terbuka publik, tempat-tempat kebugaran atau sanggar senam, klub-klub olahraga termasuk sekolah sepak bola, dan lembaga-lembaga pendidikan yang menghasilkan sarjana di bidang pendidikan jasmani dan kesehatan yang mampu memberikan kontribusi dan informasi tentang manfaat kebugaran jasmani (Sesfao, 2019).

Maksud di atas adalah materi latihan yang diberikan harus dapat diterima oleh alat-alat tubuh seperti otot, tulang, jantung, dan paru-paru dengan baik tanpa mengalami kelelahan yang berat dengan recovery atau pemulihan yang cepat dan dapat menerima materi program latihan dengan alat-alat tubuh di hari latihan. Berdasarkan penjelasan di atas penulis menyimpulkan bahwa kebugaran jasmani adalah kemampuan tubuh dalam meningkatkan derajat sehat dinamis dan tanpa menimbulkan kelelahan yang berlebihan dan sudah bugar kembali sebelum datang tugas-tugas yang baru.

\section{Komponen Kebugaran Jasmani}

Komponen jasmani secara garis besar meliputi: Daya tahan (Endurance). Daya tahan menyatakan keadaan yang menekankan pada kapasitas kerja secara terus-menerus. Dalam hal ini yang banyak dibahas adalah daya tahan kardiovaskuler dan otot (Safi'i, 2015). Pengukuran yang paling obyektif dengan mengukur oksigen yang maksimal terambil (VO2max). Pengukuran dapat dilakukan dengan berbagai macam cara seperti : berjalan, jogging, berlari pada ergometer jentera (treadmill) (Mackenzie, 2005), mengendarai ergometer sepeda (ergocycle), lari atau jalan cepat 12 menit (Ashok, 2008). Kekuatan otot (Muscle Strength). Kekuatan otot menggambarkan kontraksi maksimal yang dihasilkan oleh otot (Barjah, 1988; Sharon Wynne, 2007). Semula otot melakukan kontraksi tanpa pemendekan (isometric) sampai tercapai ketegangan yang seimbang, selanjutnya kontraksi dengan pemendekan (isotonic). (Pujiatun, 2001) Kekuatan otot yang diatur adalah kekuatan maksimal isometric. Faktor fisiologis yang mempengaruhi adalah usia, jenis kelamin, dan otot. Tenaga Ledak Otot (Muscle Explosive Power). Merupakan kemampuan otot melakukan kerja secara explosive (Kadek, Dewi, Sudiana, Luh, \& Alit, 2014). Tenaga ledak otot dipengaruhi oleh kekuatan dan kecepatan kontraksi otot (Kadek et al., 2014; Umaya, 2016). Kecepatan (speed). Kecepatan atau laju gerak dapat berlaku untuk tubuh secara keseluruhan atau bagian dari tubuh. Untuk menilai kecepatan jarak yang ditempuh harus cukup jauh agar bisa dibedakan dengan daya ledak otot (Yap, College, Brown, Cscs, \& Woodman, 2000). Faktor fisiologis yang mempengaruhi adalah : kelentukan, tipe tubuh, usia, dan jenis kelamin.

Kelincahan (Agility). Kemampuan mengubah secara cepat arah tubuh atau bagian tubuh tanpa kehilangan keseimbangan. Kelincahan tergantung pada faktor kekuatan, kecepatan, tenaga 
ledak otot, waktu reaksi, keseimbangan, dan kordinasi fkator-faktor tersebut (Yap et al., 2000). Kelentukan (Flexibility). Kelentukan merupakan suatu gerak maksimal yang dapat dilakukan oleh persendian, yang meliputi hubungan antara bentuk persendian, otot, tendo dan ligmen sekeliling persendian. Faktor fisiologis yang mempengaruhi antara lain ; usia dan aktivitas (Renold C. Ibrahim, Hedison Polii, 2015).

Keseimbangan (Balance). Keseimbangan adalah kemampuan mempertahankan sikap tubuh yang tepat pada salah satu gerakan. Kecepatan Reaksi ( Reaction Time). Kecepatan reaksi adalah waktu tersingkat yang diperlukan untuk memberikan jawaban kinetis setelah menerima suatu rangsangan (Black, 2006). Hal ini berhubungan erat dengan refleks, waktu gerakan, dan waktu respon, dan yang terakhir adalah koordinasi (Coordination). Koordinasi merupakan hubungan harmonis berbagai faktor yang terjadi pada satu gerakan. Faktor-faktor yang dimaksud adalah gerak anggota tubuh, kecepatan, pengeluaran tenaga dan sebagainya (Black, 2006).

Berdasarkan penjelasan tentang komponen kebugaran jasmani bahwa pada tingkatan Sekolah Menengah Atas dan sederajat hampir seluruh komponen kebugaran jasmani sering dilakukan disekolah dalam bentuk permainan seperti sepakbola, futsal, bolavoli, dan bolabasket. Namun agar lebih meyakinkan dan memiliki skor yang dapat memberikan penilaian berbentuk angka/nominal, penulis menggunakan tes kebugaran jasmani untuk tingkat SMA (Mackenzie, 2005).

\section{Hakekat Lemak Tubuh}

Pembahasan berikutnya adalah obesitas adalah kelebihan berat badan sebagai akibat dari penimbunan lemak tubuh yang berlebihan. Setiap orang memerlukan sejumlah lemak tubuh untuk menyimpan energi, sebagai penyekat panas, penyerap guncangan dan fungsi lainnya. Persentase lemak untuk wanita $25 \%$ sedangkan pria $15 \%$, ternyata ada perbedaan yaitu dari lemak absolute dibandingkan dengan pria serta kandungan lemak yang ada pada atlet cenderung lebih sedikit dibandingkan dengan yang bukan atlet (Hasanah, 2006)

Berdasarkan teori di atas penulis menyimpulkan bahwa kecenderungan wanita lebih banyak persentase lemaknya dibandingkan dengan laki-laki karena rata-rata lemak tubuh wanita $25 \%$ sedangkan laki-laki kisaran $15 \%$, namun hal ini bukan berarti yang selalu mengalami kegemukan adalah wanita akan tetapi laki-laki pun dapat mengalami kegemukan dengan pola makan yang tidak benar. Pada dasarnya status berat badan terbagi menjadi tiga kategori yang terdiri dari: kelebihan berat badan, beresiko, obesitas I, obesitas II (Husnah, 2012).

Kelebihan berat badan dikarenakan aktivitas olahraga kurang sedangkan penimbunan lemak yang secara bertahap dikarenakan pengaturan pola makan yang tidak teratur (Husnah, 2012). Hal ini akan berdampak pada mudahnya terserang penyakit seperti kolesterol, tekanan darah tinggi, stroke, dan jantung koroner (Khaqiqiyah \& Setiawan, 2018). Agar terhindar dari penyakit tersebut maka kita harus merubah pola hidup seperti berolahraga dan pola makan yang seimbang antara asupan makanan dengan energi yang dikeluarkan sehingga tubuh akan terasa segar dan sehat.

Lemak tidak hanya sebagai faktor yang dapat menyebabkan penyakit, namun memiliki kegunaan yang positif seperti untuk energy, selain itu juga untuk mengurangi fungsi protein sehingga protein dapat dibagi pada bagian-bagian lain, membantu buang air besar, menjaga organ-organ tubuh, penghemat protein, sebagai pengangkut protein, dan masih banyak lagi. Selain itu menahan rasa dingin pada tubuh, sebagai pelarut vitamin $A, D, E$, dan $K$, salah satu bahan vitamin dan hormone, asam kholat, empedu, penahan rasa lapar, dan yang terakhir penyusun membran sel (Khaqiqiyah \& Setiawan, 2018).

\section{Hubungan Kegemukan dengan Kebugaran Jasmani}

Kegemukan dapat diatasi dengan olahraga, namun tidak sembarang olahraga yang diberikan, hal ini tergantung dari kemampuan orang itu sendiri. Hasil penelitian mengungkapkan bahwa dengan olahraga senam dapat menurunkan kadar lemak dalam tubuh dengan kalori yang keluar adalah $66.78 \%$ dapat menurunkan berat badan, lemak tubuh $86.42 \%$, dan kadar kolesterol sebesar $27.67 \%$ (Khaqiqiyah \& Setiawan, 2018). Bukan berarti hanya olahraga senam saja yang dapat menurunkan lemak tubuh namun yang pasti bahwa untuk menjaga agar tetap berat dan 
kandungan lemak tubuh seimbang harus tetap melakukan olahraga. Namun yang masih banyak kesalahan adalah orang yang memiliki persentase lemak tinggi ketika sedang maupun sesudah melakukan olahraga tidak jarang mengkonsumsi minuman yang mengandung rasa manis atau dengan kadar gula tinggi yang mengakibatkan susah untuk penurunan lemak atau berat badan (Annas Buanasita, Andriyanto, 2015), apalagi untuk menuju ke arah kondisi fisik yang baik sangatlah jauh. Untuk itu disarankan agar mengkonsumsi minuman air putih saja lebih menyehatkan dan jauh dari resiko penyakit.

Cara lain untuk menurunkan berat tubuh karena kegemukan biasanya melakukan diet, bahkan ada yang berani melakukan diet ketat dengan banyak referensi yang tidak dianjurkan oleh kesehatan seperti diet ketat yang dapat menurunkan berat badan 8-10 $\mathrm{kg}$ hanya dengan satu minggu, hal tersebut sangat berbahaya karena dapat mengakibatkan gangguan organ tubuh. Bahkan hal tersebut apabila tidak dibarengi dengan olahraga secara teratur dapat mengembalikan berat badan semula. Untuk itu bijaksanalah dengan tubuh sendiri sesuai dengan logika pelan tapi pasti dan kontinyu hanya menurunkan 3-5 kg berat badan namun aman (Husnah, 2012).

\section{METODE PENELITIAN}

Metode penelitian yang akan digunakan adalah Metode Korelasional yang digunakan adalah Metode Korelasional yang dilakukan secara cross sectional (Dewi, Akbar, \& Yulianti, 2014) dengan tujuan untuk menghubungkan satu variabel dengan variabel lain tanpa memperhitungkan waktu pada siswa SMA N 3 Kabupaten Ciamis. Caranya adalah dengan menggunakan alat ukur skinfold califer (Mackenzie, 2005), daerah yang diukur ketebalan lemaknya :

1) Lipatan kulit pada triceps.

a. Kulit bagian belakang lengan atas dicubit dengan ibu jari dan jari telunjuk (kira-kira $1 \mathrm{~cm}$ di atas tangan yang digunakan untuk mengukur lingkaran lengan atas dan berada tepat dalam satu garis lurus dengan siku atau alecranon).

b. Skinfold calipers yang mempunyai tekanan yang sama pada setiap peregangan dari kedua tangkainya dijepitkan pada lipatan kulit di tempat yang telah ditentukan tadi.

c. Jarak antara kedua ujung tangkai Skinfold calipers yang menekan lipatan kulit dapat dilihat pada dial.

d. Pembacaan hasil dilakukan hingga 0,1 mm. Hasil dicatat dengan satuan sepersepuluh $\mathrm{mm}$.

2) Lipatan kulit di bawah tulang belikat (subscapula)

a. Pengukuran dilakukan pada setiap sudut bawah scapula kanan.

b. Lipatan kulit yang dicubit hendaklah menjurus vertikal ke bawah dan sedikit mengarah keluar.

c. Pembacaan tebal lipatan kulit hingga $0,1 \mathrm{~mm}$. Hasil dicatat dengan satuan sepersepuluh $\mathrm{mm}$.

3) Lipatan kulit suprailiaca

a. Tempat pengukuran adalah di atas spina ilimen anterior, superior.

b. Cara pengukuran dan pembacaan tebal lipatan kulit sama seperti yang telah dikemukakan.

Tabel 1.

Rata-rata (Tidak Ideal atau Ideal) Lemak Tubuh Sesuai dengan Usia dan Jenis Kelamin

\begin{tabular}{ccc}
\hline Usia (tahun) & Pria (\%) & Wanita (\%) \\
\hline 15 & 20.0 & 21.2 \\
17 & 12.0 & 28.9 \\
$18-22$ & 12.5 & 25.7 \\
$23-29$ & 14.0 & 29.0 \\
$30-40$ & 16.5 & 30.0 \\
Minimum & 21.0 & 32.0 \\
Gemuk & $>20$ & $>30$ \\
\hline
\end{tabular}

Sumber: Brian J. Sharkey (2003: 281).

Keterangan untuk tabel 1 bahwa sampel yang digunakan masuk pada rentang usia antara 15-17 tahun sesuai dengan sampel penelitian adalah kelas olahraga pada cabang olahraga bolabasket. 
Untuk variabel penelitian yang ke-dua adalah tes dan pengukuran tingkat kebugaran jasmani untuk tingkatan Sekolah Menengah Atas (Mackenzie, 2005) yang terdiri dari tes sprint $60 \mathrm{~m}$, pull-up selama 60 detik, tes sit-up 60 detik, tes lari jarak jauh 1200 m. Norma-norma untuk tes kebugaran jasmani dapat dilihat pada tabel 2.

Tabel 2.

Norma Tes Kebugaran Jasmani Indonesia Untuk Sekolah Menengah Atas

\begin{tabular}{cc}
\hline Rentang Skor & Klasifikasi nilai \\
\hline $228-k e$ atas & Baik sekali \\
$176-227$ & Baik \\
$127-175$ & Sedang \\
$78-126$ & Kurang \\
Sampai dengan 77 & Kurang sekali
\end{tabular}

Populasi yang akan dipakai oleh penulis adalah SMA N 3 Kabupaten Ciamis. Sampel yang diambil dalam penelitian ini adalah siswa kelas $\mathrm{X}$ dan $\mathrm{XI}$ dengan jumlah siswa adalah 30 orang pada kelas olahraga, artinya kelas ini memiliki perbedaan dengan kelas reguler yaitu para siswa yang memiliki prestasi di bidang olahraga bolabasket. Lokasi penelitian di lapangan bolabasket dan ruang olahraga SMA N 3 Kabupaten Ciamis. Kemudian data yang diperoleh dari hasil tes persentase lemak dengan tes kebugaran jasmani akan diolah dan dianalisis menggunakan aplikasi statistika SPSS serie 24.

\section{HASIL DAN PEMBAHASAN}

Deskripsi data dimaksudkan untuk memberi gambaran tentang data dari variabel penelitian yang diolah yang menggunakan statistik diskriptif. Adapun sebagai variabel dalam penelitian ini ada dua : 1) variabel bebas $(X)$ yaitu : persentase lemak, 2) variabel Terikat atau $(Y)$ yaitu kebugaran jasmani. Penelitian ini yang dilakukan dengan Survey test, variabel-variabel dalam penelitian ini satuan ukurannya tidak sama. Kesegaran jasmani dengan skor, dan sebagai variabel terikat adalah persentase lemak tubuh (\% Fat ) yang satuannya persen.

Uji hipotesis yang akan adalah uji signifikansi hubungan kesegaran jasmani dengan persentase lemak tubuh, menggunakan uji regresi. Adapun sebelum uji hipotesis dilakukan terlebih dahulu dilakukan uji persyaratan hipotesis yang meliputi : Uji Normalitas data, Uji Homogenitas, Uji Linieritas, Uji Keberartian model garis regresi. Langkah-langkahnya sebagai berikut :

a. Uji Normalitas Data. Uji normalitas data dalam penelitian ini dimaksudkan untuk mengetahui apakah beberapa sampel yang telah diambil berasal dari populasi yang sama atau populasi data berdistribusi normal. Uji normalitas dengan menggunakan Kolmogorov-Smirnov Test. Adapun untuk menguji normalitas data ini dengan ketentuan : jika nilai signifikansi atau nilai probabilitas > 0.05 berarti distribusi data normal, dan jika nilai signifikansi atau nilai probabilitas $<0.05$ berarti distribusi data tidak normal. Dari perhitungan statistik diperoleh hasil sebagai berikut.:

Tabel 3.

Data Hasil Tes Normalitas

\begin{tabular}{lccc}
\hline \multicolumn{1}{c}{ Variabel } & Kolmogorov-Smirnov & Signifikansi & Keterangan \\
\hline Kebugaran jasmani & 0.142 & $0.200>0.05$ & Normal \\
Persentase lemak & 0.113 & $0.200>0.05$ & Normal \\
\hline
\end{tabular}

Berdasarkan pada perhitungan nilai pada tabel 3 menunjukkan bahwa kedua variabel dalam penelitian ini secara keseluruhan datanya berdistribusi normal, sehingga uji parametrik dapat dilanjutkan.

b. Uji Homogenitas. Uji Homogenitas ini dimaksudkan adalah untuk mengetahui apakah sampelsampel dalam penelitian ini berasal dari varians yang sama dan ini merupakan prasyarat bila uji statistik infrensial hendak dilakukan, dari Santoso, 2005:209), uji homogenitas dalam penelitian ini dengan menggunakan Chi- Square dan dengan ketentuan : jika nilai signifikansi atau nilai probabilitas $>0.05$ berarti data berasal dari populasi-populasi yang mempunyai varians sama atau homogen, sedang jika nilai signifikansi atau nilai probabilitas $<0.05$ berarti data berasal dari 
populasi-populasi yang mempunyai varians tidak sama atau tidak homogen. Adapun dari perhitungan diperoleh hasil sebagai berikut:

Tabel 4.

Data Hasil Tes Homogenitas

\begin{tabular}{lccc}
\hline \multicolumn{1}{c}{ Variabel } & Nilai Chi-square & Signifikansi & Ket. \\
\hline Kesegaran Jasmani & 7.167 & $0.970>0.05$ & Homogen \\
Persentase Lemak Tubuh (\% Fat). & 0.917 & $1.000>0.05$ & Homogen \\
\hline
\end{tabular}

Dari tabel 4 tersebut diatas nampak bahwa semua data variabel dalam penelitian yang ada menunjukkan nilai signifikansi > 0.05, dengan demikian dapat disimpulkan bahwa secara keseluruhan data tersebut adalah Homogen, dan dengan demikian uji parametrik dapat dilanjutkan.

c. Uji Linieritas Garis Regresi. Uji linieritas ini dimaksudkan untuk melihat ada tidaknya hubungan antara prediktor yaitu variabel Kesegaran Jasmani $(X)$, dengan skor hasil persentase lemak tubuh (\% Fat) sebagai variabel $(Y)$. Dalam uji linieritas garis regresi ini dengan melihat nilai $F$ dengan ketentuan sebagai berikut : jika Fhitung $>$ Ftabel atau jika nilai signifikansi $<0.05$ berarti linier. Sedang jika Fhitung < Ftabel atau jika nilai signifikansi $>0.05$ berarti tidak linier . Dari perhitungan data diperoleh hasil sebagai berikut:

Tabel 5

Data Hasil UJi Linieritas Garis Regresi

\begin{tabular}{cccc}
\hline Variabel & F Hitung & Signifikan & Ket. \\
\hline Persentase lemak & 0.553 & $0.465>0.05$ & Tidak linier
\end{tabular}

Dengan melihat tabel 5 dapat dipahami bahwa variabel dalam penelitian ini, bahwa secara regresi tunggal hasil uji linieritas garis regresi menunjukkan hasil tidak linier, dengan demikian uji parametrik tidak dapat dilanjutkan. Menurut Santoso (2005:398) uji non pametriknya adalah uji Spearman, dengan demikian uji persyaratan hipotesis yang lain tidak bisa dilanjutkan.

d. Uji Hipotesis

Dalam penelitian ini bertujuan untuk mencari hubungan dari setiap variabel bebas dengan variabel terikat, karena hasil uji linieritas garis regresi menunjukkan hasil secara keseluruhan adalah tidak linier, dengan demikian uji parametrik tidak dapat dilanjutkan.Uuntuk mengetahui hubungan antar variabel apabila uji parametrik yaitu uji regresi tidak bisa dilanjutkan maka uji yang digunakan adalah uji non pametriknya yaitu uji Spearman atau Kendall's. Selanjutnya hasil uji non parametrik hasil perhitungannya adalah seperti berikut ini :

Tabel 6.

Hasil Perhitungan Uji Nonparametric Correlations Uji Spearman dan Kendall's

\begin{tabular}{|c|c|c|c|c|}
\hline \multirow[t]{6}{*}{ Kendall's tau_b } & Keb Jasmani & Correlation Coefficient & 1.000 & -.078 \\
\hline & & Sig. (2-tailed) & & .601 \\
\hline & & $\mathrm{N}$ & 24 & 24 \\
\hline & $\%$ Lemak Tubuh & Correlation Coefficient & -.078 & 1.000 \\
\hline & & Sig. (2-tailed) & .601 & \\
\hline & & $\mathrm{N}$ & 24 & 24 \\
\hline \multirow[t]{6}{*}{ Spearman's rho } & Keb Jasmani & Correlation Coefficient & 1.000 & -.129 \\
\hline & & Sig. (2-tailed) & & .548 \\
\hline & & $\mathrm{N}$ & 24 & 24 \\
\hline & \% Lemak Tubuh & Correlation Coefficient & -.129 & 1.000 \\
\hline & & Sig. (2-tailed) & .548 & \\
\hline & & $\mathrm{N}$ & 24 & 24 \\
\hline
\end{tabular}

Berdasarkan pada hasil perhitungan uji Kendall's diperoleh angka koefisien korelasi sebesar 0.078. Angka tersebut menunjukkan lemahnya korelasi antara kesegaran jasmani dengan persentase lemak tubuh atau \% Fat (di bawah 0.5), sedangkan tandanya "+" menunjukkan bahwa semakin tinggi kesegaran jasmani seseorang sampel akan semakin tipis persentase lemaknya. Demikian pula sebaliknya tubuh makin rendah kesegaran jasmaninya maka tebal pula persentase lemak tubuhnya. Kemudian selanjutnya dilakukan uji signifikansi angka korelasi, adapun hipotesis 
yang akan diuji adalah : $\mathrm{HO}$ : Tidak ada hubungan (korelasi) antara dua variasi angak korelasi $0, \mathrm{H} 1$ : Ada hubungan (korelasi) antara dua variabel atau angka korelasi tidak 0 . Uji dilakukan dengan dua sisi karena akan dicari ada atau tidaknya hubungan atau korelasi dan bukan lebih besar atau kecil. Adapun ketentuannya berdasarkan nilai probabilitas yaitu : jika probabilitas $>0.05, \mathrm{H} 0$ diterima, dan jika probabilitas $<0.05, \mathrm{HO}$ ditolak. Berdasarkan pada hasil perhitungan untuk variabel kesegaran jasmani dengan persentase lemak tubuh (\% Fat) angka signifikansi diperoleh sebesar 0.601, angka tersebut di atas 0.05 maka $\mathrm{HO}$ diterima. Dengan demikian walaupun ada hubungan antara kesegaran jasmani dengan prosentase lemak tubuh, tetapi hubungannya tidak signifikan.

\section{KESIMPULAN}

Hasil di atas dapat terjadi karena beberapa alasan yang akan dijelaskan di bawah ini adalah sebagai berikut: Karakteristik Sampel. Siswa SMP N 4 Banjar yang dijadikan sampel penelitian yang berjumlah 24 orang mempunyai latar belakang yang berbeda-beda, seperti dari pola hidup yang terdiri dari istirahat, pola makan yang berbeda-beda sehingga hubungan persentase lemak tubuh tidak terlalu signifikan dengan tingkat kebugaran jasmani. Kebiasaan hidup yang berbeda-beda. Maksudnya adalah kebiasaan hidup aktif pada siswa SMK N I Banjar berbeda-beda dikarenakan beberapa alasan salah satunya adalah minat berolahraga yang kurang pada tingkat SMP maupun SD sehingga terbawa ke jenjang berikutnya yaitu tingkatan SMK/SMA.

Program Latihan. Pemberian program latihan yang dituangkan pada materi pembelajaran olahraga di sekolah cenderung hanya sebatas penyampaian materi penjas saja yang tercantum dalam kurikulum sekolah, dan tidak diperhatikan manajemen pelaksanaan di lapangan sehingga perhatian pada mulai dari pendahuluan, latihan inti, dan penutupan diangap sebagai hal yang tidak penting terutama pada pendahuluan dan penutupan yaitu pemanasan dan cooling down.

Minat Berolahraga. Olahraga yang biasa diminati adalah olahraga permainan sehingga ketika ada beberapa siswa baik di lingkungan sekolah maupun di rumah yang tidak bisa berolahraga akhirnya semuanya tidak jadi berolahraga, contoh olahraga permainannya adalah bolavoli, sepakbola, dan futsal. Sedangkan olahraga individu seperti lari/jogging, berenang, cross country cenderung kurang diminati karena tidak ada unsur kesenangan atau have fun.

Kebugaran Jasmani. Penelitian ini menghubungkan antara persentase lemak dengan tingkat kebugaran jasmani, dengan memberikan tes kebugaran jasmani tingkat SMK N 4 Banjar yang terdiri dari tes lari $60 \mathrm{~m}$, tes angkat tubuh putra $60 \mathrm{dtk}$ dan putri $30 \mathrm{dtk}$, tes baring duduk waktunya 60 detik, est lari jauh $1200 \mathrm{~m}$ putri dan putra yang mengandung unsur kekuatan, kecepatan, dan power.

\section{REKOMENDASI}

Hasil penelitian ini penulis merekomendasikan agar sebelum dan sesudah program latihan harus dilakukan pengukuran persentase lemak menggunakan skinfold califer terutama program latihan untuk menurunkan berat badan dan untuk olahraga prestasi yang menekankan penilaian tubuh seperti cabang olahraga Binaraga dan dan Body Contest. Akhirnya penelitian ini diharapkan bermanfaat untuk diaplikasikan ke masyarakat dalam hal ini adalah dunia olahraga prestasi dan penurunan lemak tubuh untuk masyarakat umum seperti komposisi tubuh yang memiliki body shape yang diinginkan secara ideal antara tinggi badan dengan berat badan.

\section{UCAPAN TERIMAKASIH}

Terimakasih kepada pihak yang sudah memberikan dukungan pada penelitian ini yaitu SMA Negeri 3 Kabupaten Ciamis yang telah memberikan izin lokasi penelitian dan dan keterlibatan siswa kelas olahraga sebagai sampel penelitian dan tidak lupa ucapan terimakasih kepada pihak-pihak yang terkait dalam penelitian ini yang tidak dapat penulis sebutkan sehingga terlaksana penelitian ini berjalan dengan baik. 


\section{DAFTAR PUSTAKA}

Annas Buanasita, Andriyanto, I. S. (2015). Perbedaan Tingkat Konsumsi Energi, Lemak, Cairan, dan Status Hidrasi Mahasiswa Obesitas dan Non Obesitas. Indonesian Journal of Human Nutrition, 2(1), 11-22.

Ashok. (2008). Test Your Physical Fitness. New Delhi: Printed at : Singhal Print Media, Delhi.

Barjah, H. (1988). Latihan Kondisi Fisik. Modul Mandiri

Black, A. \& C. (2006). Sport and Exercise Science. London: A \& C Black Publishers Ltd.

Dewi, P. K., Akbar, I. B., \& Yulianti, A. B. (2014). Hubungan Kebugaran Jasmani Dan Lemak Tubuh Pada Kelompok Senam Dan Kelompok Tidak Senam. Prosiding Penelitian Sivitas Akademika Unisba (Kesehatan), 1016-1022.

Hasanah. (2006). Perbedaan Pengaruh Latihan Senam Aerobik Low Impack dan Body Language Terhadap Persentase Lemak Tubuh Ibu-ibu Anggota Sanggar Senam Yunita Demak. IImu Keolahragaan, 70.

Husnah. (2012). Tatalaksana obesitas. Kedokteran Syiah Kuala, 12(2), 99-104.

Kadek, N., Dewi, R., Sudiana, I. K., Luh, N., \& Alit, K. (2014). Pengaruh Pelatihan Single Leg Speed Hop dan Double Leg Speed Hop Terhadap Daya Ledak Otot Tungkai. IImu Keolahragaan, 2, 11.

Khaqiqiyah, Z., \& Setiawan, B. D. (2018). Identifikasi Tingkat Resiko Penyakit Lemak Darah Menggunakan Algoritme Backpropagation. Pengembangan Teknologi Informasi Dan IImu Komputer, 2(4), 1563-1571.

Larsen, L. (2011). Fitness and Exercise Sourcebook (Four editi; L. Larsen, Ed.). Peter E. Ruffner, Publisher Copyright @ 2011 Omnigraphics, Inc.

Mackenzie, B. (2005). Performance Evaluation Tests 101 (B. Mackenzie, Ed.). London: Jonathan Pye.

Pujiatun. (2001). Perbandingan Latihan Isotonik dan Latihan Isometrik Terhadap Kekuatan Otot Quadriseps Femoris. Universitas Diponegoro.

Renold C. Ibrahim, Hedison Polii, H. W. (2015). Pengaruh Latihan Peregangan Terhadap Fleksibilitas Lansia. Biomedik, 3(April), 328-333.

Safi' i. (2015). Profil Kondisi Fisik Pemain Futsal Putra Pra Pon Jawa Tengah Dalam Persiapan PON XIX Tahun 2015. Kondisi Fisik, 85.

Sesfao, A. (2019). Upaya Meningkatkan Kesegaran Jasmani Melalui Pendekatan Bermain Dalam Pembelajaran Pendidikan Jasmani (PenelitianTindakan Kelas di kelas VII-G SMP Negeri 14 Tasikmalaya). Jurnal Wahana Pendidikan, 5(3), 31-36.

Sharon Wynne, M. . (2007). MTEL Physical Education 22 (2nd ed.). Boston: XAMonline, Inc.

Sulasmono, R., \& Drs. Fatkur Rohman K, M. p. (n.d.). Analisis Kondisi Fisik Pemain Sepakbola SSB Tunas Jaya Sidoarjo. Sport Medicine, 62-72.

Umaya, B. I. D. A. (2016). Perbedaan Pengaruh Latihan Half Squat Jump dengan Tempo Cepat dan Tempo Lambat Terhadap Daya Ledak Otot Tungkai. Kesehatan Olahraga, 07(3), 53-61.

Yap, C. W., College, B. C., Brown, L. E., Cscs, D., \& Woodman, G. (2000). Development of Speed, Agility , and Quickness for the Female Soccer Athlete. National Strength \& Conditioning Association, 22(1), 912. 